\section{Biofouling}

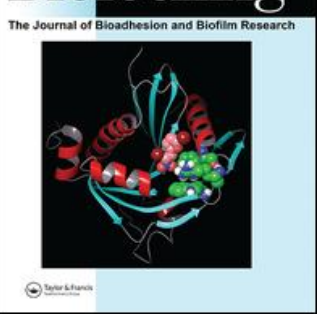

\section{Biofouling}

The Journal of Bioadhesion and Biofilm Research

\title{
KR-12-a5 is a non-cytotoxic agent with potent antimicrobial effects against oral pathogens
}

Karina Sampaio Caiaffa, Loiane Massunari, Marcelle Danelon, Gabriel Flores Abuna, Telma Blanca Lombardo Bedran, Norival Alves Santos-Filho, Denise Madalena Palomari Spolidorio, Natalia Leal Vizoto, Eduardo Maffud Cilli \& Cristiane Duque

To cite this article: Karina Sampaio Caiaffa, Loiane Massunari, Marcelle Danelon, Gabriel Flores Abuna, Telma Blanca Lombardo Bedran, Norival Alves Santos-Filho, Denise Madalena Palomari Spolidorio, Natalia Leal Vizoto, Eduardo Maffud Cilli \& Cristiane Duque (2017) KR-12-a5 is a noncytotoxic agent with potent antimicrobial effects against oral pathogens, Biofouling, 33:10, 807-818, DOI: $10.1080 / 08927014.2017 .1370087$

To link to this article: https://doi.org/10.1080/08927014.2017.1370087

册 Published online: 12 Oct 2017.

Submit your article to this journal $₫$

Џll Article views: 160

View Crossmark data \lceil

Citing articles: 2 View citing articles ๘ 


\title{
KR-12-a5 is a non-cytotoxic agent with potent antimicrobial effects against oral pathogens
}

\author{
Karina Sampaio Caiaffa ${ }^{a}$ (D) Loiane Massunaria (D), Marcelle Danelon ${ }^{b}$ (D) , Gabriel Flores Abunac (D),

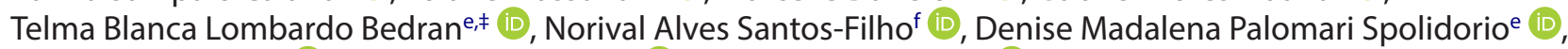 \\ Natalia Leal Vizoto ${ }^{d}$ (D) Eduardo Maffud Cillif (D) and Cristiane Duque ${ }^{b}$ (D)
}

\begin{abstract}
aSão Paulo State University (UNESP), Department of Restorative Dentistry, School of Dentistry, Araçatuba, Brazil; bSão Paulo State University (UNESP), Department of Pediatric Dentistry and Public Health, School of Dentistry, Araçatuba, Brazil; CUniversity of Campinas (UNICAMP), Department of Restorative Dentistry, School of Dentistry, Piracicaba, Brazil; dUniversity of Campinas (UNICAMP), Department of Oral Diagnosis, School of Dentistry, Piracicaba, Brazil; eSão Paulo State University (UNESP), Department of Physiology and Pathology, School of Dentistry, Araraquara, Brazil; ‘São Paulo State University (UNESP), Department of Biochemistry and Chemical Technology, Institute of Chemistry, Araraquara, Brazil
\end{abstract}

\section{ABSTRACT}

This study evaluated the cytotoxicity and antimicrobial activity of analogs of cationic peptides against microorganisms associated with endodontic infections. L-929 fibroblasts were exposed to LL-37, KR-12-a5 and hBD-3-1C and chlorhexidine (CHX, control), and cell metabolism was evaluated with MTT. The minimal inhibitory concentration (MIC) and the minimal bactericidal/fungicidal concentration (MBC/MFC) of the peptides and $\mathrm{CHX}$ were determined against oral pathogens associated with endodontic infections. Enterococcus faecalis and Streptococcus mutans biofilms were cultivated in bovine dentin blocks, exposed to different concentrations of the most efficient antimicrobial peptide and analyzed by confocal laser scanning microscopy. CHX and peptides affected the metabolism of L-929 at concentrations $>31.25$ and $500 \mu \mathrm{g} \mathrm{ml}^{-1}$, respectively. Among the peptides, KR-12-a5 inhibited growth of both the microorganisms tested with the lowest MIC/ $\mathrm{MBC} / \mathrm{MFC}$ values. In addition, KR-12-a5 significantly reduced $E$. faecalis and S. mutans biofilms inside dentin tubules. In conclusion, KR-12-a5 is a non-cytotoxic agent with potent antimicrobial and antibiofilm activity against oral pathogens associated with endodontic infections.

\section{ARTICLE HISTORY}

Received 13 November 2016 Accepted 17 August 2017

KEYWORDS

Biofilms; cationic antimicrobial peptides; cell culture; microbial sensitivity tests

\section{Introduction}

In endodontic therapy the chemical-mechanical preparation does not allow full disinfection of the root canal system due to complex systems of accessory and lateral canals and the persistence of some microbial species. This makes the use of intracanal medication (Byström and Sundqvist 1981; Chávez De Paz et al. 2003) a necessary practice. Gram-negative bacteria, commonly found in primary infections, are generally eliminated from root canal systems after chemical-mechanical treatment, except for some anaerobic bacilli, such as Fusobacterium species. However, Gram-positive bacteria are commonly present in these conditions, particularly Streptococcus, Actinomyces and Enterococcus species, among others (Iglesias-Linares et al. 2013).

Defensins and cathelicidins are the most common and important cationic antimicrobial peptides (CAMP) found in the oral cavity. The most common $\beta$-defensins (hBDs) are hBD-1, -2 and -3 , produced by epithelial cells, including oral mucosa. They have immunomodulatory functions that modify cell migration and maturation, inducing cytokines and the release of histamine and prostaglandin A2 from mast cells (Wiesner and Vilcinskas 2010). The peptide fragment LL-37 is provided by the action of proteases on human cationic peptide-18 and also produced by epithelial cells. LL-37 has broad antimicrobial activity (Vandamme et al. 2012) and exerts immunomodulatory effects, including the chemotactic effect of neutrophils and eosinophils (Tjabringa et al. 2006), prostaglandin E2 production in gingival fibroblasts (Chotjumlong et al. 2013), attenuation of cytokine production induced by lipopolysaccharides (LPS) and the expression of chemokines in fibroblasts (Jönsson and Nilsson 2012).

Short peptides or analogs of peptides based on original CAMP have attracted attention because of their potential low production cost and the possibility of optimizing

CONTACT Cristiane Duque cristianeduque@yahoo.com.br, cduque@foa.unesp.br

†Present address: Department of Periodontology, Nove de Julho University, São Paulo, Brazil.

(C) 2017 Informa UK Limited, trading as Taylor \& Francis Group 
their antimicrobial and immunological properties (Taylor et al. 2008; Wang 2008; Jacob et al. 2013; Kreling et al. 2016). Taylor et al. (2008) synthesized an analog of hBD-3, called hBD-3-1C $\mathrm{V}$, with five of the six cysteines changed to alanines, leaving only the fifth cysteine in its original position. This peptide analog was equally chemotactic for monocytes and $\mathrm{T}$ cells and maintained the inhibitory effect against Pseudomonas aeruginosa and Staphylococcus aureus when compared to the original hBD-3. The analog of LL-37, KR-12-a5 exhibited potent antimicrobial activity against important Gram-positive and Gram-negative bacteria and the highest LPS-binding activity (Jacob et al. 2013). The objective of this study was to evaluate the cytotoxicity and antimicrobial activity of analogs of CAMP against microorganisms associated with endodontic infections.

\section{Materials and methods}

\section{Peptide synthesis}

The peptides used in this study and their amino acid sequences were: LL-37 (LLGDFFRKSKEKIGKEFKRIVQRIKDFLRNLVPRTES- $\mathrm{NH}_{2}$ ) (Ji et al. 2007), KR-12-a5 (KRIVKLILKWLR-NH ${ }_{2}$ ) (Jacob et al. 2013) and hBD-3-1C ${ }^{\mathrm{V}}$ (GIINTLQKYYARVRGGRAAVLSALPKEEQIGKASTRGRKCARRKK-NH ${ }_{2}$ ) (Taylor et al. 2008). All peptides were synthesized at the Institute of Chemistry, UNESP, Araraquara, SP, Brazil. Solid phase peptide synthesis was performed manually (Crusca et al. 2011) using the method previously described by Merrifield (1963) and Kaiser et al. (1970), using Fmoc (9-fluorenylmethyloxycarbonyl) protocols on the Rink-amide resin. The molecular masses of the peptides were determined using mass spectrometry, with a positive ion-mode electrospray ionization (ESI) apparatus (Bruker GmbH, Bremen, Germany) and were in agreement with corresponding calculated values. Purification of synthesized peptides was performed in a semi-preparative reverse-phase high performance liquid chromatography (RP-HPLC) Beckman System Gold on a reverse phase $\mathrm{C} 18$ column $(2.1 \times 25 \mathrm{~cm}$, Phenomenex, Torrance, CA, USA). Final purity levels of peptides reached at least $95 \%$ on a Shimadzu chromatography equipped with an analytical C18 reverse phase column $(0.46 \times 25 \mathrm{~cm}$, Kromasil, Bohus, Sweden $)$.

\section{Circular dichroism spectroscopy}

Spectra were obtained at wavelengths between 190 and $260 \mathrm{~nm}$ using a JASCO J-815 circular dichroism (CD) spectrophotometer with nitrogen flush in $1 \mathrm{~mm}$ path length quartz cuvettes at room temperature. In order to investigate the conformational changes, spectra were recorded in an aqueous and lysophosphatidylcholine (LPC) $10 \mathrm{mM}$ solution. The peptide concentration was
$30 \mu \mathrm{M}$. CD spectra were typically recorded as an average of five scans and the resultant spectra were normalized to residual molar ellipticity $[\theta]$.

\section{Preparation of antimicrobial agents}

Peptides were weighed with an analytical balance (OHAUS Corporation, Parsippany, NJ, USA) at a concentration of $4 \mathrm{mg} \mathrm{ml}^{-1}$ and dissolved in sterile deionized water, except for $\mathrm{hBD}-3-1 \mathrm{C}^{\mathrm{V}}$, which was dissolved in $0.045 \%\left(\mathrm{v} \mathrm{v}^{-1}\right)$ trifluoroacetic acid (TFA) $/ \mathrm{H}_{2} \mathrm{O}$. Chlorhexidine digluconate (CHX) (Sigma-Aldrich, St Louis, MO, USA) was dissolved in sterile deionized water at $20 \mathrm{mg} \mathrm{ml}^{-1}$. All solutions were filtered using $0.2 \mu \mathrm{m}$ syringe filters (Kasvi, Curitiba, PR, Brazil). All subsequent experiments were performed in triplicate, in three independent assays.

\section{Cytotoxicity assays}

Cytotoxicity assays were conducted according to Bedran et al. (2014). Briefly, L-929 fibroblast cultures were grown in Dulbecco's modified Eagle's medium (DMEM; Gibco, Grand Island, NY, USA) supplemented with 10\% fetal bovine serum (FBS; Gibco) and $100 \mathrm{IU} \mathrm{ml}^{-1}$ of penicillin, $100 \mu \mathrm{g} \mathrm{ml}^{-1}$ of streptomycin and $2 \mathrm{mmol} \mathrm{l}^{-1}$ of glutamine (Gibco) in a humidified incubator under $5 \% \mathrm{CO}_{2}$ and $95 \%$ air at $37^{\circ} \mathrm{C}$ (Isotemp Fisher Scientific, Pittsburgh, PA, USA). After the formation of a monolayer, L-929 cultures were submitted to trypsin treatment (TrypLETM Express, Life Technologies, Carlsbad, CA, USA) for $5 \mathrm{~min}$ at $37^{\circ} \mathrm{C}$. Trypsin inhibitor at $0.3 \mathrm{mg} \mathrm{ml}^{-1}$ was added to the cultures and cells were harvested by centrifugation $(500 \mathrm{~g}$ for $5 \mathrm{~min}$ ), suspended in fresh medium and seeded in a 96-well microplate $\left(200 \mu \mathrm{l} \mathrm{well}^{-1}, 7 \times 10^{5}\right.$ cells ml $\left.^{-1}\right)$. After $24 \mathrm{~h}$ incubation, cells were stimulated with peptides and the control CHX at $1.95-2,000 \mu \mathrm{g} \mathrm{ml}^{-1}$. The cell metabolism was assessed by the methyl tetrazolium (MTT) assays after $24 \mathrm{~h}$ exposure (Bedran et al. 2014). The means were calculated for the groups and transformed into percentage cell viability in relation to the negative control (DMEM), which was defined as having $100 \%$ cell metabolism.

\section{Antimicrobial activity}

\section{Microbial strains and growth conditions}

The following standard strains were used: facultative anaerobic bacteria - Enterococcus faecalis (ATCC 51299), Streptococcus mutans (ATCC 25175) and Actinomyces israelii (ATCC 12102); strict anaerobic bacteria - Porphyromonas gingivalis (ATCC 33277) and Fusobacterium nucleatum (NCTC 11326) and the aerobic yeast Candida albicans (ATCC 26790), all of those kindly provided by Oswaldo Cruz Foundation (FIOCRUZ - Rio de Janeiro, São Paulo, 
Brazil). Microbial suspensions were prepared from cultures previously grown in brain heart infusion agar (BHIA; Difco Laboratories, Detroit, MI, USA) for S. mutans, A. israelii and E. faecalis and incubated at $37^{\circ} \mathrm{C}$ for $24 \mathrm{~h}$ in a 5\% $\mathrm{CO}_{2}$ atmosphere (Incubator Ultra Safe, HF212-UV, Heal Force, Shangai, China). Candida albicans was cultured in Sabouraud dextrose agar (SDA) (Difco) containing $40 \mathrm{mg} \mathrm{ml}^{-1}$ of chloramphenicol (Sigma-Aldrich) at $37^{\circ} \mathrm{C}$ under aerobic conditions. P. gingivalis and F. nucleatum were grown in blood-agar (Difco) containing BHIA, $5 \mathrm{mg} \mathrm{ml}^{-1}$ of hemin, $10 \mathrm{mg} \mathrm{ml}^{-1}$ of menadione, yeast extract powder (YE, Difco) and 5\% defibrinated sheep blood at $37^{\circ} \mathrm{C}$ in an anaerobic chamber $\left(10 \% \mathrm{H}_{2}, 10 \% \mathrm{CO}_{2}\right.$ and $80 \%$ $\mathrm{N}_{2}$ ) (Don Whitley Scientific MG500, Shipley, UK). For subsequent microbiological assays, standard optical density was established for each microorganism: 0.5 for facultative anaerobic bacteria and $F$. nucleatum $\left(1-5 \times 10^{8} \mathrm{CFU} \mathrm{ml}^{-1}\right)$, 0.2 for $P$. gingivalis $\left(1-5 \times 10^{3} \mathrm{CFU} \mathrm{ml}^{-1}\right)$ and 0.3 for Candida albicans $\left(1-5 \times 10^{6} \mathrm{CFU} \mathrm{ml}^{-1}\right)$ at $550-600 \mathrm{~nm}$ (Biotek Instruments, Winooski, VT, USA).

\section{Determination of MIC and MBC/MFC concentrations}

Minimum inhibitory concentrations (MIC) and minimum bactericidal or fungicidal concentrations (MBC/ MFC) were obtained using the microdilution method with 96-well microtiter plates, based on the criteria of the CLSI M27-A3 (2008) for yeast, the CLSI M7-A9 (2012) for bacteria, and modifications proposed by Mor et al. (1994). The final concentration of bacterial suspension inside wells was $1-5 \times 10^{5} \mathrm{CFU} \mathrm{ml}^{-1}$ for bacteria and

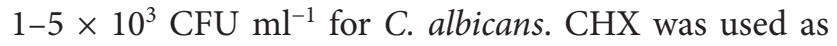
positive control and cultures without antimicrobial agents were used as negative controls. All antimicrobial agents were serially diluted in sterile deionized water (or TFA/ water for $\mathrm{hBD}-3-1 \mathrm{C}^{\mathrm{V}}$ ) at concentrations ranging from 1.95 to $4,000 \mu \mathrm{g} \mathrm{ml}^{1}$. The microplates were incubated at $37^{\circ} \mathrm{C}$ for 4 and $24 \mathrm{~h}$ for all microorganisms, except F. nucleatum and $P$. gingivalis, which were incubated for 48 and $72 \mathrm{~h}$, respectively. After incubation with $0.01 \%$ resazurin staining (Sigma-Aldrich) for $4 \mathrm{~h}$, the MIC was defined as the last blue well (microbial inhibition) on the side of the first pink well (microbial growth). MBC or MFC were obtained when the antimicrobial agents killed $100 \%$ of the microbial strains, after plating the content of the blue wells in BHIA for S. mutans, A. israelii and E. faecalis, SDA for C. albicans and blood-agar for F. nucleatum and P. gingivalis and counting of colonies forming units $\left(\mathrm{CFU} \mathrm{ml}{ }^{-1}\right)$.

\section{Biofilm assays}

\section{Dentin block preparation and bacterial infection}

Biofilm assays for confocal laser scanning microscope (CLSM) analysis were conducted with E. faecalis and
S. mutans, testing the peptide with the most efficient antimicrobial activity (MIC/MBC assays) and CHX. For this analysis, bovine roots were prepared according to the method proposed by Ma et al. (2011) with some modifications. Briefly, bovine roots ( $n=3$ /group) were sectioned horizontally $1 \mathrm{~mm}$ below the cement-enamel junction to obtain a dentin block with a length of $4 \mathrm{~mm}$. Root canals were enlarged with Gates Glidden drill\#6 (1.5 mm diameter) (Dentsply Sirona, York, PA, USA) at $300 \mathrm{rpm}$ at low speed. Each cylindrical dentin block was fractured into two semi cylindrical halves. The outer surfaces of halves were ground by 600 -grit silicon carbide paper to achieve a standard thickness of $2 \mathrm{~mm}$ and then shaped with a fine carbide bur until reaching the final size of $3 \times 3 \times 2 \mathrm{~mm}$. The blocks were cleaned in an ultrasonic bath using initially 17\% EDTA solution (for $3 \mathrm{~min}$ ) and then distilled water (for $5 \mathrm{~min}$ ). After cleaning, the blocks were dried, sterilized and inserted in a microtube with the canal side up. Gaps between the dentin block and inner wall of tube were sealed by resin composite (3M ESPE, Maplewood, MN, USA) and light cured for $40 \mathrm{~s}$. Five hundred microliters of E. faecalis or $S$. mutans suspension at $10^{7} \mathrm{CFU} \mathrm{ml} \mathrm{m}^{-1}$ in $\mathrm{BHI}$ broth were added to each microtube with dentin blocks inside. The microtubes were sequentially harvested at 1,400, 2,000, 3,600 and 5,600 g, twice each, for $5 \mathrm{~min}$. A fresh suspension of bacteria was inserted between every centrifugation and the last solution was discarded.

Dentin blocks were incubated individually in 24-well plates in BHI broth for seven days, replacing the culture medium every $48 \mathrm{~h}$. After this period, blocks were washed twice with sterile saline and transferred, under aseptic conditions, to a new plate and exposed to KR-12-a5 and $\mathrm{CHX}$ at 250 and $500 \mu \mathrm{g} \mathrm{ml}^{-1}$ for $24 \mathrm{~h}$. After that, dentin blocks were washed twice again and cut into transverse slices of $1 \mathrm{~mm}$ thickness using a precision cutter and polished with 1,200 grit sandpaper disks.

\section{Confocal laser scanning microscope (CLSM) analysis}

After washing with sterile water, dentin blocks were stained with $100 \mu \mathrm{l}$ of fluorescent LIVE/DEAD BacLight Bacterial Viability stain (L13152, Molecular Probes, Eugene, OR, USA) containing SYTO9 and propidium iodide, according to the manufacturer's instructions. The excitation/emission wavelengths were $480 / 500 \mathrm{~nm}$ for SYTO 9 and 490/635 $\mathrm{nm}$ for propidium iodide. Two additional uninfected specimens were stained using the same protocol as negative controls. The mounted specimens were observed using a $63 \times$ NA1.4 oil immersion lens. CLSM images were acquired using the software LAS AF (Leica Microsystems, Buffalo Grove, IL, USA). The $\mathrm{Z}$ stack was obtained from the top until the bottom of the biofilms. Using a $0.5 \mu \mathrm{m}$ interval stack between 
each frame, five randomly selected areas of each dentin specimen were made for each sample. Each 2-D image was obtained by the max projection of the $\mathrm{Z}$ stack. The 3-D image was reconstructed using Image $J$ software (Rasband, W.S., Image J, US National Institutes of Health, Bethesda, MD, USA, https://imagej.nih.gov/ij/, 19972016). The ratio of red fluorescence to green-and-red fluorescence in the 2-D images indicated the proportion of dead cells for each antimicrobial agent/concentration. The quantification of biofilm thickness was determined using 3-D image reconstructions.

\section{Statistical analysis}

All results are presented as mean values \pm standard deviation (SD). Differences between groups were analyzed by analysis of variance (ANOVA) followed by Tukey's multiple comparison test using statistic software SPSS 17.0 (SPSS Inc., Chicago, IL, USA).

\section{Results}

\section{HPLC analysis}

The relative hydrophobicity of peptides was determined by the differences in the elution times obtained from RP-HPLC. In this case, a relationship between hydrophobicity and biological activity was not observed. Regarding the net charges of the peptides, a relationship between absolute positive charge and antimicrobial activity was also not observed (Table 1). However, a correlation between the percentage of positive charge and antimicrobial activity was observed. KR-12-a5 presented $42 \%$ positive residues, whilst LL-37 and hBD $-3-1 \mathrm{C}^{\mathrm{V}}$ presented 29 and $28 \%$ positive residues, respectively.

\section{Circular dichroism spectroscopy (CD spectra)}

$\mathrm{CD}$ spectra of the peptides were carried out in aqueous and LPC $10 \mathrm{mM}$ solutions. When in LPC solution, LL-37 and KR-12-a5 exhibited a spectrum attributed mainly to an $\alpha$-helix structure (negative peak at 208 and $222 \mathrm{~nm}$ and positive peak near $193 \mathrm{~nm}$ ) (Figure 1A and B). In addition, CD analysis of $\mathrm{hBD}-3-1 \mathrm{C}^{\mathrm{V}}$ in LPC displayed a spectrum of a disordered structure containing a helical conformation. These results suggest a relationship between the antimicrobial activity and presence of helical structure (Figure 1C).

\section{Cytotoxicity tests}

CHX severely affected L-929 cell metabolism at concentrations $>31.25 \mu \mathrm{g} \mathrm{ml}^{-1}$, while the peptides affected cell growth at concentrations above $500 \mu \mathrm{g} \mathrm{ml}^{-1}$. KR-12-a5 and hBD-3-1C $\mathrm{C}^{\mathrm{V}}$ were statistically different when applied at $125-500 \mu \mathrm{g} \mathrm{ml}^{-1}(p<0.05)$. However, KR-12-a5 did not differ from LL-37 for any of the concentrations tested (Figure 2) $(p>0.05)$.

\section{MIC and MBC/MFC assays}

Among the peptides, KR-12-a5 had the highest bactericidal activity for all exposure times, with the MIC ranging from 1.95 to $62.5 \mu \mathrm{g} \mathrm{ml}^{-1}$ and the $\mathrm{MBC} / \mathrm{MFC}$ from 3.91 to $62.5 \mu \mathrm{g} \mathrm{ml}^{-1}$. LL-37 showed antimicrobial action against $S$. mutans, $A$. israelii, $F$. nucleatum and $P$. gingivalis (MIC/MBC range: $3.91-1,000 \mu \mathrm{g} \mathrm{ml}^{-1}$ ), but not for E. faecalis (MIC/MBC range: $1,000-2,000 \mu \mathrm{g} \mathrm{ml}^{-1}$ ). The growth of C. albicans was affected only by KR-12-a5 and CHX, considering the concentrations tested in the present study $\left(<4,000 \mu \mathrm{g} \mathrm{ml}^{-1}\right)$. A similar inhibitory effect was observed for hBD-3-1C $\mathrm{C}^{\mathrm{V}}$ and LL-37 against S. mutans and A. israelii. Among the peptides, hBD$3-1 \mathrm{C}^{\mathrm{V}}$ had the lowest effect against $F$. nucleatum (MIC/ MBC: $1,000 \mu \mathrm{g} \mathrm{ml}{ }^{-1}$ ). However, hBD-3-1C $\mathrm{C}^{\mathrm{V}}$ had higher effects against $P$. gingivalis with $\mathrm{MIC} / \mathrm{MBC}$ of 31.25 and $62.5 \mu \mathrm{g} \mathrm{ml}{ }^{-1}$, respectively. KR-12-a5 and CHX had substantial antimicrobial effects at the non-toxic concentrations (Table 2).

\section{Biofilm assays}

Representative 2-D and 3-D CLSM images of E. faecalis and S. mutans biofilms on dentin blocks exposed to KR-12-a5 and CHX can be observed in Figures 3 and 4. The analysis of the proportion of dead cells obtained from 2-D images showed that KR-12-a5 caused significant effects against $E$. faecalis biofilms, similar to that observed with CHX. The effects increased with the concentration. For S. mutans there was also an increase in the anti-biofilm activity of KR-12-a5 and CHX when comparing the concentrations

Table 1. Characteristics of the peptides: synthesis and purification.

\begin{tabular}{|c|c|c|c|c|c|}
\hline Peptide & Sequence & Retention Time (min) & Mass $\left(\mathrm{g} \mathrm{mol}^{-1}\right)$ & Net charge & $\%$ Positive residues \\
\hline LL-37 & $\begin{array}{l}\text { LLGDFFRKSKEKIGKEFKRIVQ } \\
\text { RIKDFLRNLVPRTES }\end{array}$ & 17.53 & $4,492.35$ & +4 & 29 \\
\hline KR-12-a5 & KRIVKLILKWLR & 13.65 & $1,565.07$ & +5 & 42 \\
\hline hBD-3-1CV & $\begin{array}{l}\text { GIINTLQKYYARVRGGRAAVLSAL } \\
\text { PKEEQIGKASTRGRKCARRKK }\end{array}$ & 12.91 & $4,999.92$ & +11 & 28 \\
\hline
\end{tabular}



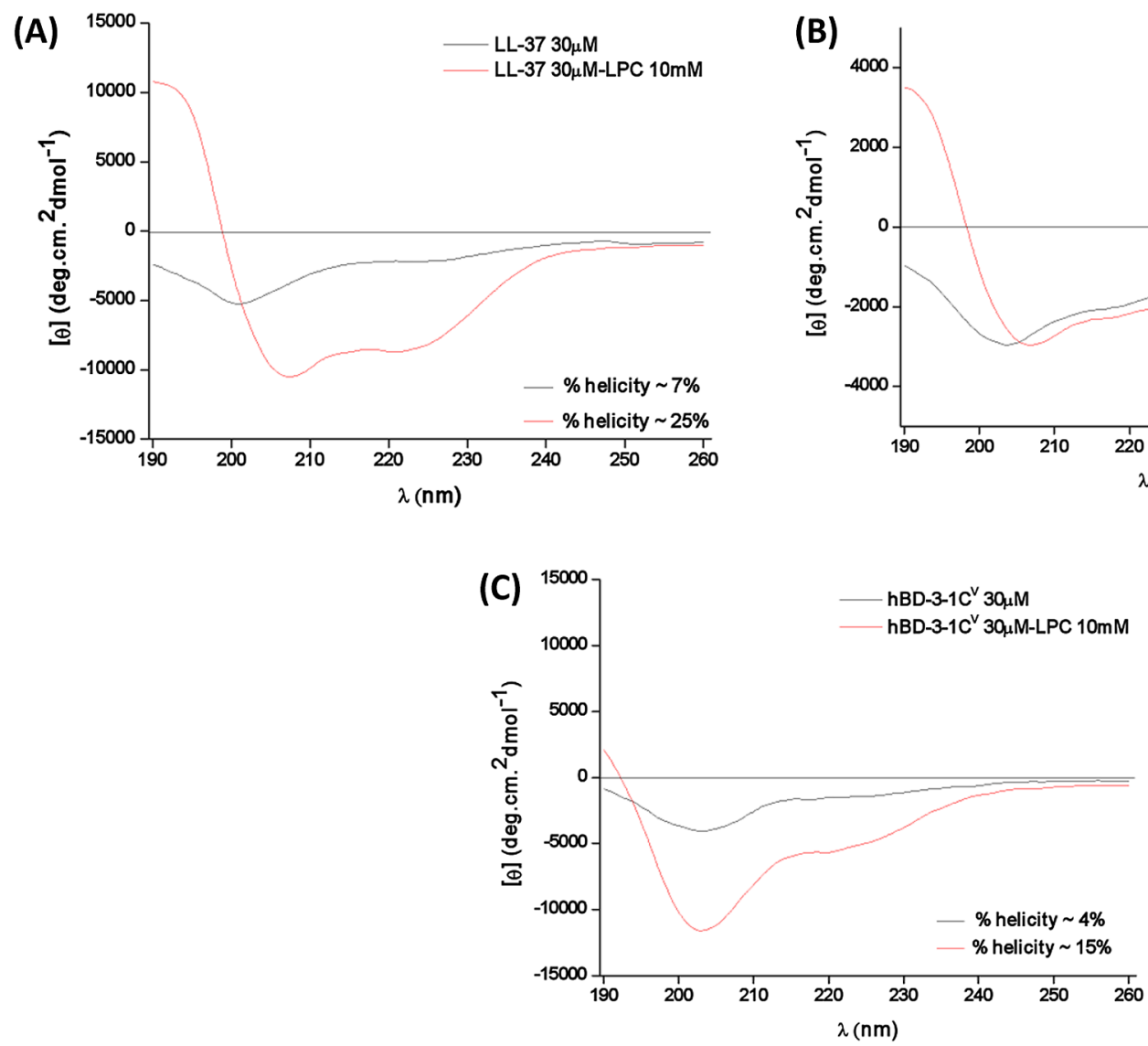

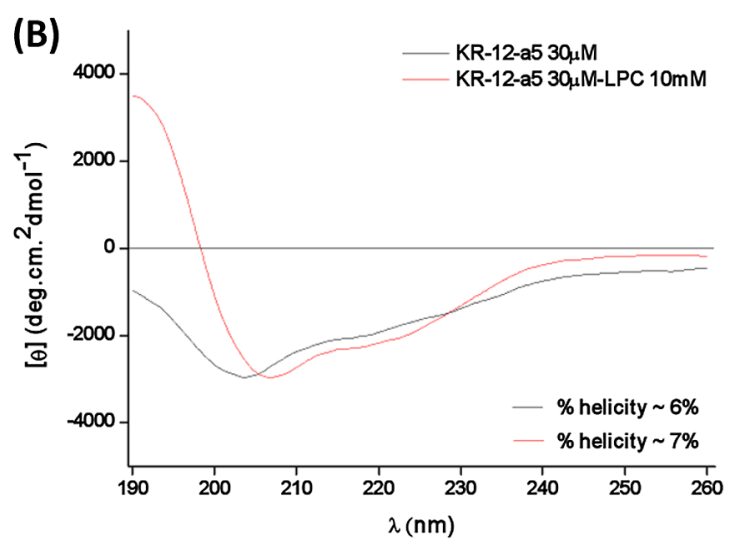

hBD-3-1 $\mathrm{C}^{\mathrm{V}} 30 \mathrm{\mu M}$

Figure 1. Circular dichroism of cationic peptides analogs in different environments. The spectra for LL-37 (A), KR-12-a5 (B) and hBD3-1C (C) were measured in aqueous (black lines) or $10 \mathrm{mM} \mathrm{LPC}$ solution (red lines) and determined the conformational changes. LL-37 and KR-12-a5 exhibited a spectrum attributed mainly to an a-helix structure and hBD-3-1C displayed a spectrum of a disordered structure containing a helical conformation.

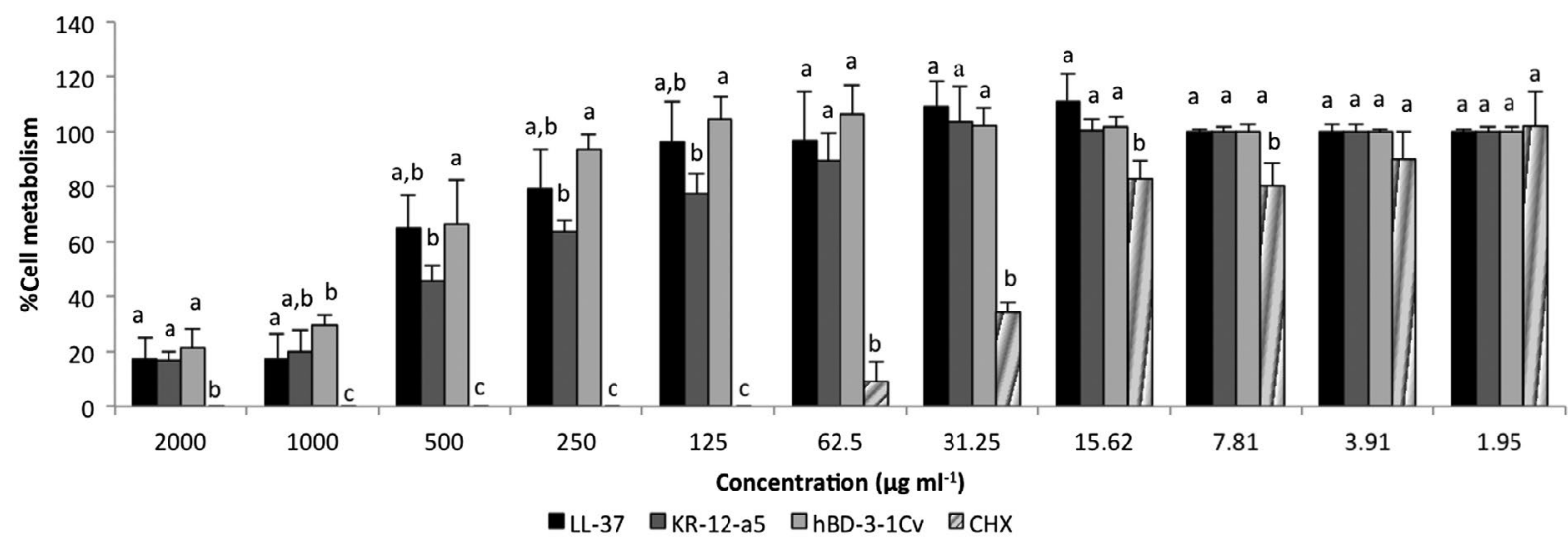

Figure 2. Effect of different concentrations of cationic peptide analogs on the viability of fibroblasts cells (L-929). The results are expressed as means \pm SDs. Means were calculated for the groups and transformed into percentage cell viability in relation to the negative control (untreated cells), which was defined as having $100 \%$ cell metabolism. Different lower letters show statistical differences among the groups (peptides and $\mathrm{CHX}$ ), considering each concentration separately, according to ANOVA and Tukey tests.

of 250 and $500 \mu \mathrm{g} \mathrm{ml}^{-1}$. Regardless of the concentration, CHX had a significantly higher effect against $S$. mutans biofilms inside dentin tubules than KR-12-a5 (Figure 5). A reduction in the biofilm thickness was observed when
KR-12-a5 and CHX were applied against both bacteria, with the exception of CHX against S. mutans (Figure 6). This effect increased when increasing the concentration from 250 to $500 \mu \mathrm{g} \mathrm{ml}^{-1}$. 
Table 2. The MIC and MBC/MFC values $\left(\mu \mathrm{g} \mathrm{ml}^{-1}\right)$ obtained for the cationic peptide analogs and CHX at different exposure times.

\begin{tabular}{|c|c|c|c|c|c|}
\hline & & LL-37 & KR-12-a5 & HBD-3-1C & $\mathrm{CHX}$ \\
\hline \multirow[t]{4}{*}{$4 h$} & S. mutans & $250(1,000)$ & $3.91(3.91)$ & $250(250)$ & $0.03(7.81)$ \\
\hline & A. israelii & $3.91(3.91)$ & $1.95(3.91)$ & $7.81(7.81)$ & $0.48(0.98)$ \\
\hline & E. faecalis & $1,000(1,000)$ & 31.25 (31.25) & $500(>4,000)$ & $3.91(15.62)$ \\
\hline & C. albicans & $>4,000(>4,000)$ & $15.62(15.62)$ & $>4,000(>4,000)$ & $7.81(7.81)$ \\
\hline \multirow[t]{4}{*}{$24 h$} & S. mutans & $250(1,000)$ & $3.91(7.81)$ & $250(250)$ & $0.24(7.81)$ \\
\hline & A. israelii & $7.81(7.81)$ & $3.91(3.91)$ & 7.81(7.81) & $0.98(0.98)$ \\
\hline & E. faecalis & $2,000(2,000)$ & $62.5(62.5)$ & $500(>4,000)$ & $7.81(15.62)$ \\
\hline & C. albicans & $>4,000(>4,000)$ & $15.62(31.25)$ & $>4,000$ & $7.81(7.81)$ \\
\hline \multirow[t]{2}{*}{$48-72 \mathrm{~h}$} & F. nucleatum & $250(250)$ & $7.81(7.81)$ & $1,000(1,000)$ & $1.95(1.95)$ \\
\hline & P. gingivalis & $7.81(7.81)$ & $3.91(3.91)$ & $31.25(62.5)$ & $7.81(7.81)$ \\
\hline
\end{tabular}

\section{Discussion}

The persistence of some microorganisms in the root canal and periapical tissues after treatment with conventional endodontic materials has led to the search for new alternative products with broad range antimicrobial activity. LL-37 and hBD-3 are recognized antimicrobial peptides, but their use is limited by difficulties with chemical synthesis and mammalian cell toxicity (Batoni et al. 2011). This present study evaluated two analogs of these peptides, KR-12-a5 and hBD-3-1C , respectively. KR-12-a5 was the most effective peptide against the selected oral bacteria and C. albicans. The antimicrobial activity of KR-12 and its analogs was first tested against B. subtilis, S. epidermidis, $S$. aureus (Gram-positive bacteria), E. coli, P. aeruginosa and S. typhimurium (Gram-negative bacteria). Compared with the parent peptide LL-37, all these peptides, including KR-12-a5, showed equal or higher activity in the planktonic condition (Jacob et al. 2013). In addition, KR-12-a5 presented the highest lipopolysaccharide (LPS)-binding and neutralizing effect, improving its ability to control bacterial infection (Jacob et al. 2013).

In the present study, it was demonstrated for the first time that KR-12-a5 was also effective in reducing seven-day preformed biofilms of E. faecalis and S. mutans into dentin tubules. The original peptide LL-37 and its fragments have shown their action against preformed biofilms of $P$. aeruginosa (Overhage et al. 2008; Nagant et al. 2012) and Acinetobacter baumannii (Feng et al. 2013) and in preventing biofilm formation by $C$. albicans, $S$. aureus and E. coli (Luo et al. 2017). A recent study showed the potential of KR-12-a5 and its analogs in inhibiting multidrug-resistant Pseudomonas aeruginosa biofilm formation, in concentrations much lower than LL-37 (Kim et al. 2017). In the present study, KR-12-a5 was less efficient than CHX in reducing $S$. mutans biofilms by CLSM. CHX is a broad-spectrum antimicrobial agent with potent effect against Gram-positive bacteria, particularly S. mutans (Järvinen et al. 1993; Grönroos et al. 1995). Although CHX has been used as an efficient agent for oral biofilm control (Zanatta et al. 2007), few studies evaluated the effects of CHX on biofilms in a dose and time-dependent manner (Hope and Wilson 2004; Silva et al. 2014). Silva et al. (2014) showed that the minimal concentration to eradicate $18 \mathrm{~h}$ - preformed biofilm was $800 \mu \mathrm{g} \mathrm{ml}^{-1}$. However, high concentrations of $\mathrm{CHX}$ showed in vitro cytotoxicity (Lessa et al.2010; Kreling et al. 2016) and over an extended time may result in local adverse effects on the oral mucosa (Hepso et al. 1988).

In the current study, $\mathrm{hBD}-3-1 \mathrm{C}^{\mathrm{V}}$ presented antimicrobial activity against most of the bacteria tested. This hBD-3 analog caused a similar effect on $S$. mutans and A. israelii, but a lower effect against $F$. nucleatum and $P$. gingivalis when compared with LL-37 and KR-12-a5. The findings corroborated the results obtained by Ouhara et al. (2005) for the original hBD-3, except for F. nucleatum. Those authors demonstrated excellent antimicrobial action for both hBD-3 and LL-37 against several oral pathogens, such as $A$. actinomycetemcomitans, $P$. gingivalis, $P$. intermedia, F. nucleatum, S. mutans, S. sobrinus, S. salivarius, $S$. sanguinis, $S$. mitis and $L$. casei. The antimicrobial effect of two peptide fragments of hBD-3 mouse orthologue (D6-17 and D1-23) was recently tested against oral pathogens. In comparison with LL-37, peptide fragments have demonstrated a superior effect against Streptococcus spp. and a lower effect on Lactobacillus and Actinomyces species (Kreling et al. 2016). Recombinant hBD-3 synthetic peptides (rhBD-3) were effective against $S$. aureus and some pathogenic microorganisms also found in endodontic infections, such as $S$. mutans, A. naeslundii, E. faecalis, C. albicans and F. nucleatum (Song et al. 2009). In this present study, E. faecalis showed more resistance to hBD$3-1 C^{\mathrm{V}}$. Anti-C. albicans activity was not found for hBD$3-1 C^{\mathrm{V}}$, differently from the original peptide hBD-3 (Won et al. 2011). The lower antimicrobial effect of hBD-3-1-C $\mathrm{C}^{\mathrm{V}}$ in comparison to original hBD-3 could be related to a reduction in its hydrophobicity as a result of the replacement of cysteines by alanines (Klüver et al. 2005). Taylor et al. (2008) developed the only study that evaluated the antimicrobial activity of $\mathrm{hBD}-3-1 \mathrm{C}^{\mathrm{V}}$ and they found a higher inhibitory effect against $P$. aeruginosa and $S$. aureus. 

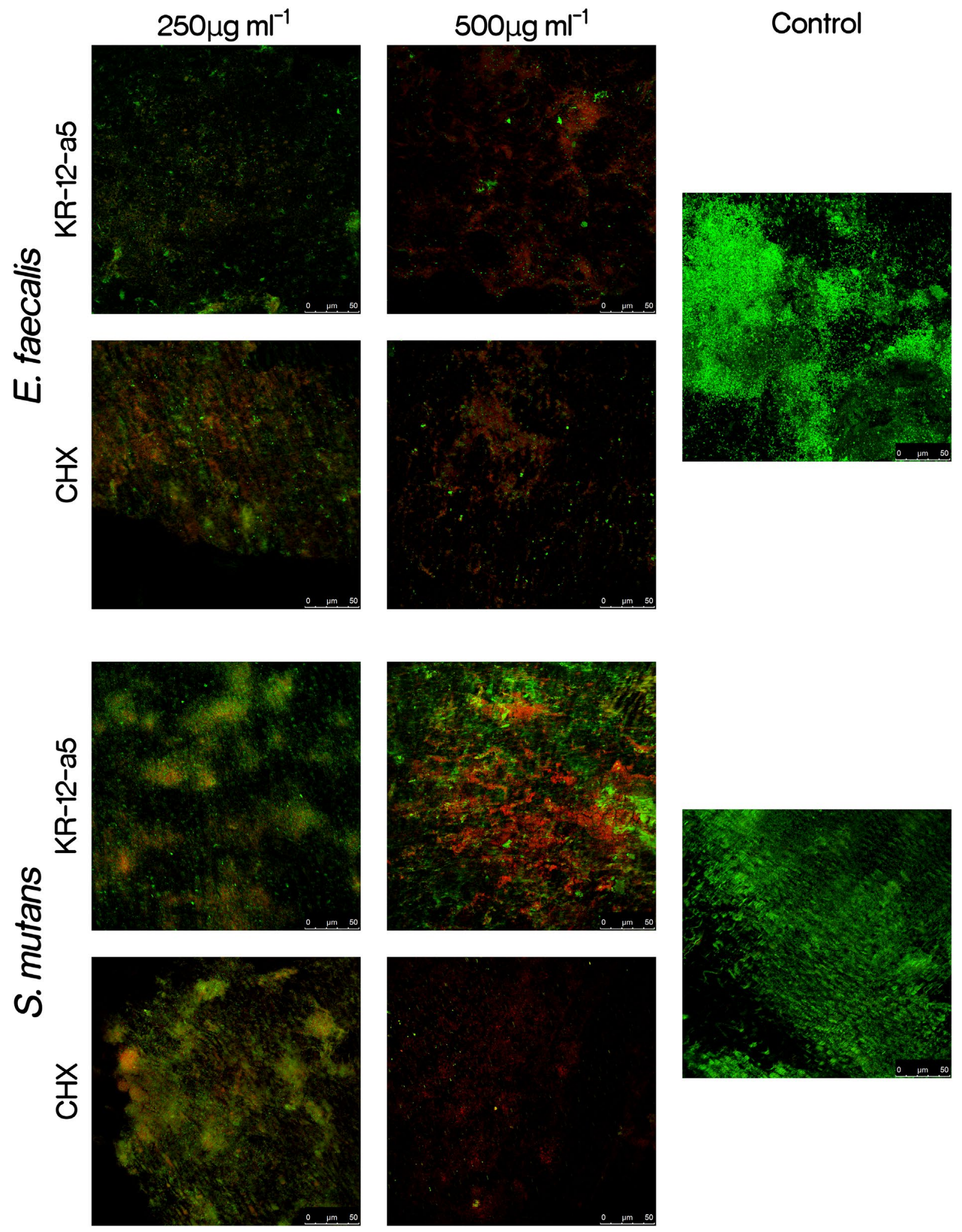

Figure 3. Representative 2-D CLSM images of E. faecalis and S. mutans biofilms on dentin blocks exposed to different concentrations of KR-12-a5 and CHX.

In order to evaluate the effects of the structure on the biological activity of peptides, the conformations adopted by the peptides were analyzed using $\mathrm{CD}$ spectra (Figure 1A, B and C). LL-37 and KR-12-a5, as observed in previous studies (Johansson et al. 1998, 2013), showed a predominantly disordered structure in aqueous solution. In LPC solution, both peptides exhibited a spectrum attributed mainly to an $\alpha$-helix structure (negative peak at 208 and 


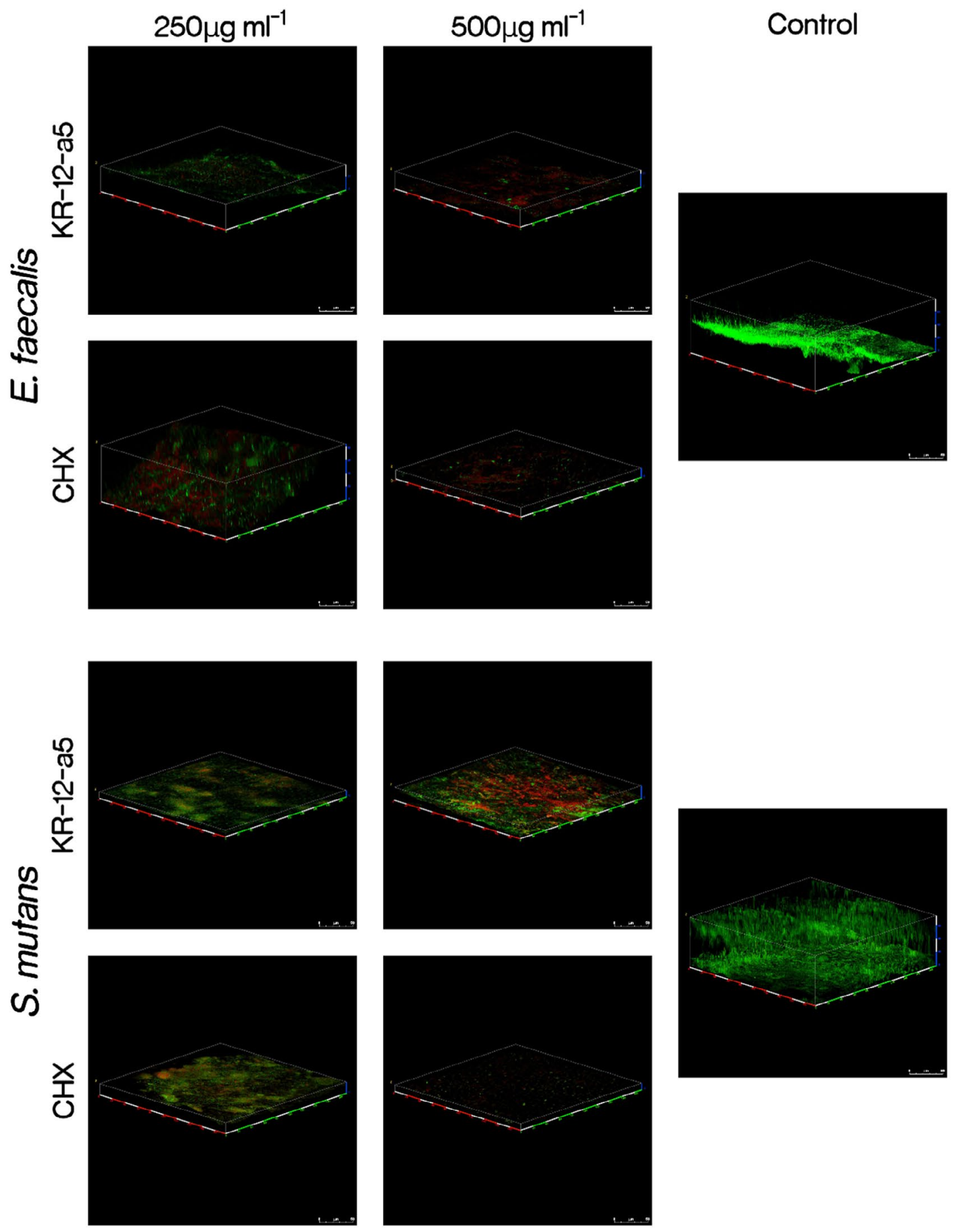

Figure 4. Representative 3-D CLSM images of E. faecalis and S. mutans biofilms on dentin blocks exposed to different concentrations of KR-12-a5 and CHX.

$222 \mathrm{~nm}$ and positive peak near $193 \mathrm{~nm}$ ). In addition, CD analysis of $\mathrm{hBD}-3-1 \mathrm{C}^{\mathrm{V}}$ in LPC displayed an a spectrum of a disordered structure containing a helical conformation. These data show that hBD-3-1C , which does not present the three hBD-3 characteristic disulfide bonds, probably lost part of its secondary content, with anti-parallel $\beta$-sheets and a helical segment (Schibli et al. 2002; Taylor et al. 2008). In this study, the antimicrobial activities of LL-37 and KR-12-a5 were higher than those of hBD-3-1C $\mathrm{C}^{\mathrm{V}}$, suggesting a relationship between the antimicrobial activity and the presence of a helical structure. This relationship was also observed in the study of Wang et al. (2017), which reported high $\alpha$-helical content for the GH12, synthetic cationic peptide with potent inhibiting and killing activity against cariogenic bacteria, with MICs of 4.0-8.0 $\mu \mathrm{g} \mathrm{ml}^{-1}$ and MBCs of 8.0-32.0 $\mu \mathrm{g} \mathrm{ml}^{-1}$. Amphipathic $\alpha$-helical 


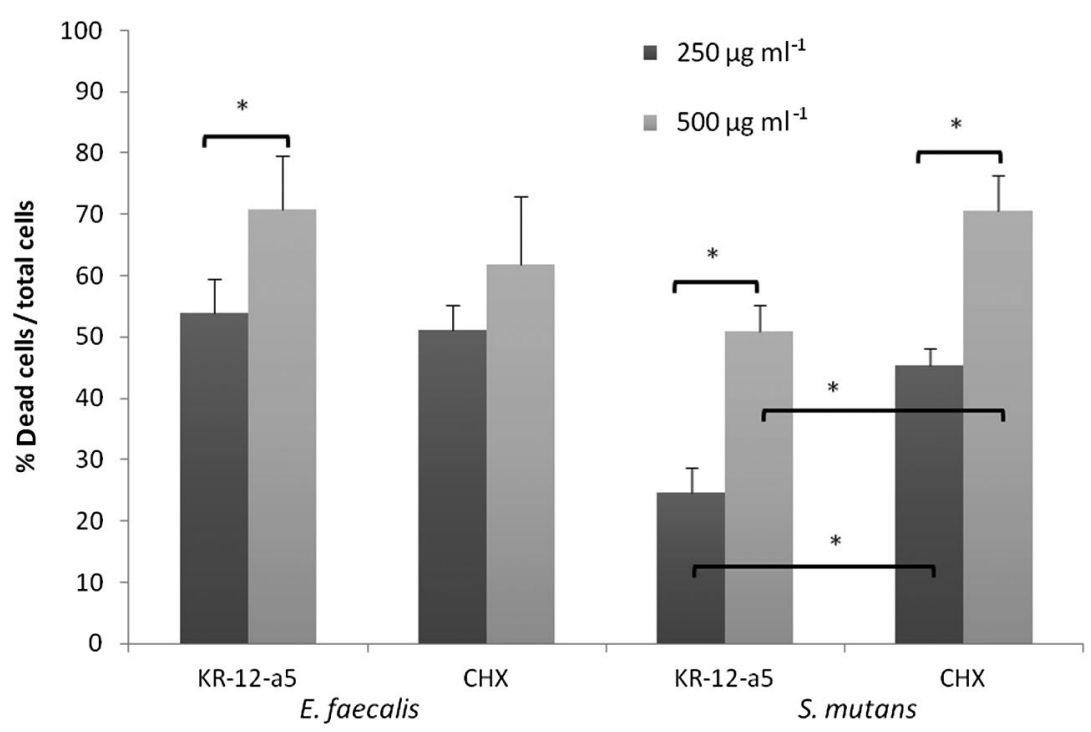

Figure 5. Proportion of dead cells obtained after 2-D CLSM analysis of E. faecalis and S. mutans biofilms on dentin blocks after exposure to different concentrations of KR-12-a5 and $-\mathrm{CHX}$. The results are expressed as means \pm SDs.

*Statistical difference between the groups, considering each bacterial species separately, according to ANOVA/Tukey tests $(p<0.05)$.

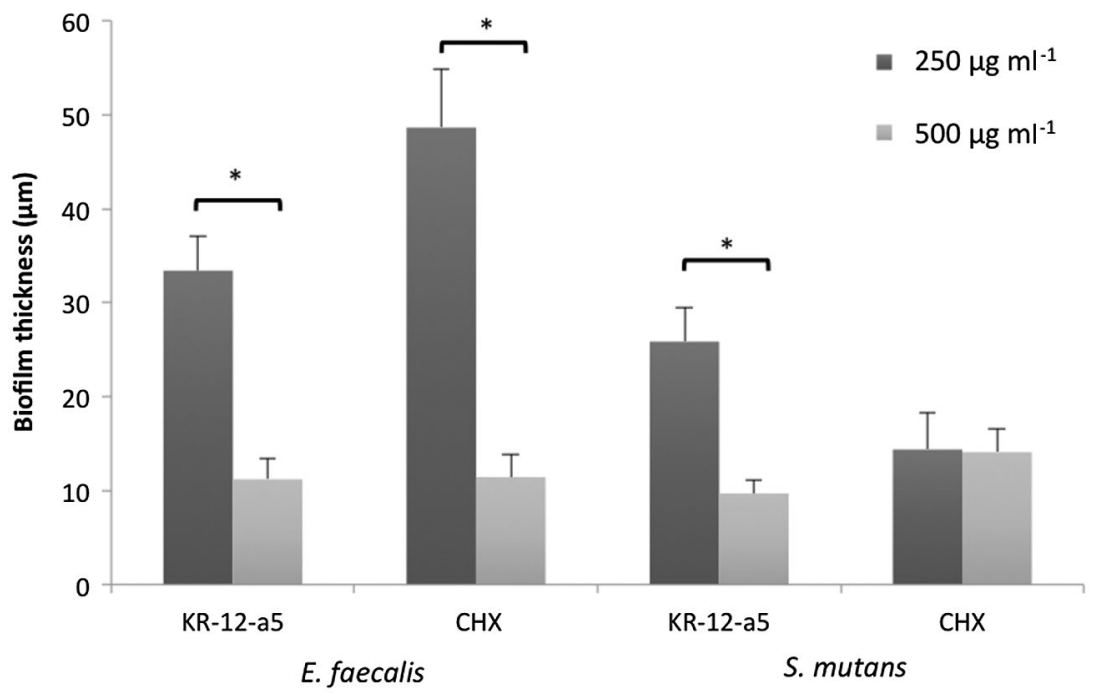

Figure 6. Biofilm thickness (in $\mu \mathrm{m}$ ) obtained after 3-D CLSM analysis of E. faecalis and S. mutans biofilm on dentin blocks after exposure to different concentrations of KR-12-a5 and CHX. The results are expressed as means \pm SDs.

*Statistical difference between the groups, considering each bacterial species separately, according to ANOVA/Tukey tests $(p<0.05)$.

peptides appear to require two features to be effective antimicrobial agents: net positive charge, which attracts them to the anionic microbial surface and the ability to assume an amphipathic structure, which favors penetration through microbial membranes (Brogden 2005).

The relative hydrophobicity of these peptides was determined by the differences in the elution times obtained from RP-HPLC. Most natural CAMPs have a net positive charge ranging from +4 to +6 and a $40-60 \%$ content of hydrophobic residues (Giangaspero et al. 2001). The structural parameters of KR-12-a5 are within the optimal ranges (net charge: +5 and positive residues: $42 \%$ ), suggesting a relationship between peptide net charge and hydrophobicity and biological activity (Table 1). Although Jacob et al. (2013) observed no linear correlation between the positive charge of short KR-12 analogs and antimicrobial activity, a delicate balance between hydrophobicity and charge of the peptides was notable for optimal activity. Furthermore, Rosenfeld et al. (2010) reported that an increase in the ratio between hydrophobicity and the charge of peptides could improve both antimicrobial and LPS neutralization effects. In this context it is interesting to note that 
KR-12-a5 was designed to increase its hydrophobic angle when compared to the original KR-12 (Jacob et al. 2013). This study proposed that both structure (helicity) and relative positive charge are essential for the increase in the antimicrobial activity.

The toxicity of peptides on host cells at therapeutic concentrations may be a limitation for peptide use for therapeutic purposes. Studies have shown that LL-37 was toxic to human peripheral blood leukocytes and T-cell line (Johansson et al. 1998) at concentrations $>13 \mu \mathrm{M}$ (58 $\mu \mathrm{g} \mathrm{ml}^{-1}$ ) and to epithelial cells above $20 \mu \mathrm{M}$ (90 $\mu \mathrm{g} \mathrm{ml}^{-1}$ ) (Kreling et al. 2016). hBD-3 showed toxicity against dendritic cells and keratinocytes at a range of 18.2-35.9 $\mu \mathrm{g} \mathrm{ml}^{-1}\left(80-160 \mu \mathrm{g} \mathrm{ml}^{-1}\right.$ ) (Leelakanok et al. 2015). Klüver et al. (2005) investigated hBD-3 analogs with differences in the location of disulfide bonds, sequence length, net charge and hydrophobicity. Those authors demonstrated that the substitution of cysteines by alanines caused a reduction in the overall hydrophobicity, making hBD-3 analogs less cytotoxic to THPcells, a cell monocyte line, in comparison to the original ones. In the present study, all peptides severely affected the metabolism of fibroblast cells (L-929) at concentrations $>500 \mu \mathrm{g} \mathrm{ml}^{-1}$. The cytotoxicity of KR-12-a5 was statistically similar to LL-37, but it showed more toxicity than hBD-3-1C $\mathrm{C}^{\mathrm{V}}$ between 125 and $500 \mu \mathrm{g} \mathrm{ml}$. Jacob et al. (2013) showed that KR-12-a5 was toxic to macrophages at concentrations above $12.5 \mu \mathrm{M}\left(\sim 20 \mu \mathrm{g} \mathrm{ml}^{-1}\right)$. Compared with the other KR-12 analogs, KR-12-a5 had the highest hydrophobicity, which probably increased its cell toxicity (Jacob et al. 2013). In the present study, all peptides were less cytotoxic than $\mathrm{CHX}$, considering the concentrations tested.

The cationic property of CAMPs is important for antimicrobial activity and could help to explain their low toxicity. The cell membrane of bacteria has a high concentration of acidic phospholipids, such as phosphatidylglycerol and cardiolipin, and its surface contains anionic molecules, such as lipopolysaccharides (Gram-negative bacteria), teichoic acids and lipoteichoic acids (Gram-positive bacteria). As such, the membranes of bacterial cells are more negatively charged than those of mammalian cells, being composed of zwitterionic phosphatidylcholine and sphingomyeli (Matsuzaki 2009).

In conclusion, KR-12-a5 is a non-cytotoxic agent with potent antimicrobial and anti-biofilm activities against oral pathogens associated with endodontic infections.

\section{Acknowledgements}

The authors would like to thank the Center of Microscopy and Images, from the Piracicaba School of Dentistry (FOP-UNICAMP) for their support on CLSM.

\section{Disclosure statement}

The authors declare that they have no conflict of interest.

\section{Funding}

This work was supported by the São Paulo Research Foundation (FAPESP) [grant numbers \#2012/12235-5, 2013/246065, \#2012/15346-7]; PROPe/CDC-UNESP [grant number \#0403/001/14]; National Council for Scientific and Technological Development (CNPq) [grant number \#134551/2013-3]. $\mathrm{EMC}$ is a senior researcher at $\mathrm{CNPq}$.

\section{ORCID}

Karina Sampaio Caiaffa (iD) http://orcid.org/0000-0002-8159$727 \mathrm{X}$

Loiane Massunari (D) http://orcid.org/0000-0001-5626-7087

Marcelle Danelon (iD http://orcid.org/0000-0003-2091-649X

Gabriel Flores Abuna (D) http://orcid.org/0000-0002-9812-4882

Telma Blanca Lombardo Bedran (D) http://orcid.org/00000002-3579-6147

Norival Alves Santos-Filho (D) http://orcid.org/0000-0002-03446900

Denise Madalena Palomari Spolidorio (D) http://orcid.org/00000003-2376-1024

Natalia Leal Vizoto (D) http://orcid.org/0000-0002-9307-3502

Eduardo Maffud Cilli iD http://orcid.org/0000-0002-4767-0904

Cristiane Duque (D) http://orcid.org/0000-0002-2575-279X

\section{References}

Batoni G, Maisetta G, Brancatisano FL, Esin S, Campa M. 2011. Use of antimicrobial peptides against microbial biofilms: advantages and limits. Curr Med Chem. 18:256279. doi:10.2174/092986711794088399

Bedran TB, Mayer MP, Spolidorio DP, Grenier D. 2014. Synergistic anti-inflammatory activity of the antimicrobial peptides human beta-defensin-3 (hBD-3) and cathelicidin (LL-37) in a three-dimensional co-culture model of gingival epithelial cells and fibroblasts. PLoS ONE. 9:e106766. doi:10.1371/journal.pone.0106766

Brogden KA. 2005. Antimicrobial peptides: pore formers or metabolic inhibitors in bacteria?. Nat Rev Microbiol. 3:238-250.

Byström A, Sundqvist G. 1981. Bacteriological evaluation of the efficacy of mechanical root canal instrumentation in endodontic therapy. Scand J Dent Res. 89:321-328.

Chávez De Paz LE, Dahlén G, Molander A, Möller A, Bergenholtz G. 2003. Bacteria recovered from teeth with apical periodontitis after antimicrobial endodontic treatment. Int Endod J. 36:500-508. doi:10.1046/j.13652591.2003.00686.x

Chotjumlong P, Bolscher JG, Nazmi K, Reutrakul V, Supanchart C, Buranaphatthana W, Krisanaprakornkit S. 2013. Involvement of the $\mathrm{P} 2 \mathrm{X} 7$ purinergic receptor and c-Jun N-terminal and extracellular signal-regulated kinases in cyclooxygenase- 2 and prostaglandin $\mathrm{E} 2$ induction by LL37. J Innate Immun. 5:72-83. doi:10.1159/000342928

CLSI - Clinical and Laboratory Standard Institute. 2008. Method for broth dilution antifungal susceptibility testing of yeast; approved standard. 3rd ed. Wayne, PA, CLSI document, M27-A3. 
CLSI - Clinical and Laboratory Standard Institute. 2012. Methods for dilution antimicrobial susceptibility tests for bacteria that grow aerobically; approved standard. 9thed. Wayne, PA, CLSI document, M7-A9.

Crusca E, Rezende AA, Marchetto R, Mendes-Giannini MJS, Fontes W, Castro MS, Cilli EM. 2011. Influence of Nterminus modifications on the biological activity, membrane interaction, and secondary structure of the antimicrobial peptide Hylina1. Biopolymers. 96:41-48. doi:10.1002/bip. v96.1

Feng X, Sambanthamoorthy K, Palys T, Paranavitana C. 2013. The human antimicrobial peptide LL-37 and its fragments possess both antimicrobial and antibiofilm activities against multidrug-resistant Acinetobacter baumannii. Peptides. 49:131-137. doi:10.1016/j.peptides.2013.09.007

Giangaspero A, Sandri L, Tossi A. 2001. Amphipathic alpha helical antimicrobial peptides. Eur J Biochem. 268:55895600. doi:10.1046/j.1432-1033.2001.02494.x

Grönroos L, Mättö J, Saarela M, Luoma AR, Jousimies-Somer H, Pyhälä S, Asikainen S, Alaluusua S. 1995. Chlorhexidine susceptibilities of mutans streptococcal serotypes and ribotypes. Antimicrob Agents Chemother. 39:894-898. doi:10.1128/AAC.39.4.894

Hepso HU, Bjornland T, Skoglund LA. 1988. Sid-effects and patient acceptance of $0.2 \%$ versus $0.1 \%$ chlorhexidine used as post-operative prophylactic mouthwash. Int J Oral Maxillofac Surg. 17:17-20. doi:10.1016/S09015027(88)80222-4

Hope CK, Wilson M. 2004. Analysis of the effects of chlorhexidine on oral biofilm vitality and structure based on ivability profiling and an indicator of membrane integrity. Antimicrob Agents Chemother. 48:1461-1468. doi:10.1128/ AAC.48.5.1461-1468.2004

Iglesias-Linares A, Yáñez-Vico RM, Sánchez-Borrego E, Moreno-Fernández AM, Solano-Reina E, MendozaMendoza A. 2013. Stem cells in current paediatric dentistry practice. Arch Oral Biol. 58:227-238. doi:10.1016/j. archoralbio.2012.11.008

Jacob B, Park IS, Bang JK, Shin SY. 2013. Short KR-12 analogs designed from human cathelicidin LL37 possessing both antimicrobial and antiendotoxic activities without mammalian cell toxicity. J Pept Sci. 19:700-707. doi:10.1002/ psc.v19.11

Järvinen H, Tenovuo J, Huovinen P. 1993. In vitro susceptibility of Streptococcus mutans to chlorhexidine and six other antimicrobial agents. Antimicrob Agents Chemother. 37:1158-1159. doi:10.1128/AAC.37.5.1158

Ji S, Hyun J, Park E, Lee BL, Kim KK, Choi Y. 2007. Susceptibility of various oral bacteria to antimicrobial peptides and to phagocytosis by neutrophils. J Periodontal Res. 42:410-419. doi:10.1111/jre.2007.42.issue-5

Johansson J, Gudmundsson GH, Rottenberg ME, Berndt KD, Agerberth B. 1998. Conformation-dependent antibacterial activity of the naturally occurring human peptide LL-37. J Biol Chem. 273:3718-3724. doi:10.1074/jbc.273.6.3718

Jönsson D, Nilsson BO. 2012. The antimicrobial peptide LL-37 is anti-inflammatory and proapoptotic in human periodontal ligament cells. J Periodontal Res. 47:330-335. doi:10.1111/jre.2012.47.issue-3

Kaiser E, Colescott RL, Bossinger CD, Cook PI. 1970. Color test for detection of free terminal amino groups in the solidphase synthesis of peptides. Anal Biochem. 34:595-598. doi:10.1016/0003-2697(70)90146-6
Kim EY, Rajasekaran G, Shin SY. 2017. LL-37-derived antimicrobial peptide KR-12-a5 and its d-amino acid substituted analogs with cell selectivity, anti-biofilm activity, synergistic effect with conventional antibiotics, and antiinflammatory activity. Eur J Med Chem. 18:428-441. doi:10.1016/j.ejmech.2017.05.028

Klüver E, Schulz-MarondeS Scheid S, Meyer B, Forssmann WG, Adermann K. 2005. Structure-activity relation of human beta-defensin 3: influence of disulfide bonds and cysteine substitution on antimicrobial activity and cytotoxicity. Biochemistry. 44:9804-9816. doi:10.1021/bi050272 k

Kreling PF, Aida KL, Massunari L, Caiaffa KS, Percinoto C, Bedran TB, Spolidorio DM, Abuna GF, Cilli EM, Duque C. 2016. Cytotoxicity and the effect of cationic peptide fragments against cariogenic bacteria under planktonic and biofilm conditions. Biofouling. 32:995-1006. doi:10.1080/08 927014.2016.1218850

Leelakanok N, Fischer CL, Bates AM, Guthmiller JM, Johnson GK, Salem AK, Brogden KA, Brogden NK. 2015. Cytotoxicity of HBD3 for dendritic cells, normal human epidermal keratinocytes, hTERT keratinocytes, and primary oral gingival epithelial keratinocytes in cell culture conditions. Toxicol Lett. 239:90-96.

Lessa FCR, Aranha AMF, Nogueira I, Giro EMA, Hebling J, Costa CAS. 2010. Toxicity of chlorhexidine on odontoblastlike cells. J Appl Oral Sci. 18:50-58. doi:10.1590/S167877572010000100010

Luo Y, McLean DT, Linden GJ, McAuley DF, McMullan R, Lundy FT. 2017. The naturally occurring host defense peptide, LL-37, and its truncated mimetics KE-18 and KR12 have selected biocidal and antibiofilm activities against Candida albicans, Staphylococcus aureus, and Escherichia coli in vitro. Front Microbiol. 31:544.

Ma J, Wang Z, Shen Y, Haapasalo M. 2011. A new noninvasive model to study the effectiveness of dentin disinfection by using confocal laser scanning microscopy. J Endod. 37:1380-1385. doi:10.1016/j.joen.2011.06.018

Matsuzaki K. 2009. Control of cell selectivity of antimicrobial peptides. Biochimica et Biophysica Acta (BBA). Biomembranes. 1788:1687-1692. doi:10.1016/j. bbamem.2008.09.013

Merrifield RB. 1963. Solid phase peptide synthesis. I. The synthesis of a tetrapeptide. J Am Chem Soc. 2149-2154. doi:10.1021/ja00897a025

Mor A, Hani K, Nicolas PJ. 1994. The vertebrate peptide antibiotics dermaseptins have overlapping structural features but target specific microorganisms. J Biol Chem. 269:31635-31641.

Nagant C, Pitts B, Nazmi K, Vandenbranden M, Bolscher JG, Stewart PS, Dehaye JP. 2012. Identification of peptides derived from the human antimicrobial peptide LL-37 active against biofilms formed by Pseudomonas aeruginosa using a library of truncated fragments. Antimicrob Agents Chemother. 56:5698-5708. doi:10.1128/AAC.00918-12

Ouhara K, Komatsuzawa H, Yamada S, Shiba H, Fujiwara T, Ohara M, Sayama K, Hashimoto K, Kurihara H, Sugai M. 2005. Susceptibilities of periodontopathogenic and cariogenic bacteria to antibacterial peptides, \{beta\}defensins and LL37, produced by human epithelial cells. J Antimicrob Chemother. 55:888-896. doi:10.1093/jac/ dki103

Overhage J, Campisano A, Bains M, Torfs E, Rehm B, Hancock R. 2008. Human host defense peptide LL-37 prevents 
bacterial biofilm formation. Infect Immun. 76:4176-4182. doi:10.1128/IAI.00318-08

Rosenfeld Y, Lev N, Shai Y. 2010. Effect of the hydrophobicity to net positive charge ratio on antibacterial and anti-endotoxin activities of structurally similar antimicrobial peptides. Biochemistry. 49:853-861. doi:10.1021/bi900724x

Schibli DJ, Hunter HN, Aseyev V, Starner TD, Wiencek JM, McCray PB Jr, Tack BF, Vogel HJ. 2002. The solution structures of the human beta-defensins lead to a better understanding of the potent bactericidal activity of HBD3 against Staphylococcus aureus. J Biol Chem. 277:8279-8289. doi:10.1074/jbc.M108830200

Silva ACB, Stipp RN, Mattos-Graner RO, Sampaio FC. 2014. Influence of sub-lethal and lethal concentrations of chlorhexidine on morphology and glucosyltransferase genes expression in Streptococcus mutans UA159. Adv Microbiol. 4:945-954. doi:10.4236/aim.2014.413105

Song W, Shi Y, Xiao M, Lu H, Qu T, Li P, Wu G, Tian Y. 2009. In vitro bactericidal activity of recombinant human beta-defensin-3 against pathogenic bacterial strains in humantooth root canal. Int J Antimicrob Agents. 33:237243. doi:10.1016/j.ijantimicag.2008.05.022

Taylor K, Clarke DJ, McCullough B, Chin W, Seo E, Yang D, Oppenheim J, Uhrin D, Govan JR, Campopiano DJ, et al. 2008. Analysis and separation of residues important for chemoattractant and antimicrobial activities of betadefensin3. J Biol Chem. 283:6631-6639. doi:10.1074/jbc. M709238200
Tjabringa GS, Ninaber DK, Drijfhout JW, Rabe KF, Hiemstra PS. 2006. Human cathelicidin LL-37 is a chemoattractant for eosinophils and neutrophils that acts via formylpeptide receptors. Int Arch Allergy Immunol. 140:103-112. doi: $10.1159 / 000092305$

Vandamme D, Landuyt B, Luyten W, Schoofs L. 2012. A comprehensive summary of LL-37, the factotum human cathelicidin peptide. Cell Immunol. 280:22-35. doi:10.1016/j.cellimm.2012.11.009

Wang G. 2008. Structures of human host defense cathelicidin LL-37 and its smallest antimicrobial peptide KR-12 in lipid micelles. J Biol Chem. 283:32637-32643. doi:10.1074/jbc. M805533200

Wang Y, Fan Y, Zhou Z, Tu H, Ren Q, Wang X, Ding L, Zhou X, Zhang L. 2017. De novo synthetic short antimicrobial peptides against cariogenic bacteria. Arch Oral Biol. 25:4150. doi:10.1016/j.archoralbio.2017.03.017

Wiesner J, Vilcinskas A. 2010. Antimicrobial peptides - the ancient arm of the human immune system. Virulence. 1:440-464. doi:10.4161/viru.1.5.12983

Won JH, Ng TB, Legowska A, Rolka K, Hui M, Cho CH. 2011. Antifungal action of human cathelicidin fragment (LL1337) on Candida albicans. Peptides. 32:1996-2002.

Zanatta FB, Antoniazzi RP, Rösing CK. 2007. The effect of $0.12 \%$ chlorhexidine rinsing in previously plaque-free and plaquecovered surfaces. A randomized controlled clinical trial. J Periodontol. 78:2127-2213. doi:10.1902/jop.2007.070090 